\title{
The Agony and Ecstasy of Being Black and Female: A True Voice of African American Women Poets
}

\author{
Vijaya K Raman \\ English Department, Rajalakshmi Engineering College, Chennai, India \\ Email: viji.murari@gmail.com
}

\begin{abstract}
Black women poets have made a significant contribution to African American Literature. They have written, both as Black and women, addressing the inequalities of Race and Gender. For a long time, Black women were mute spectators of discrimination against them. But in the twentieth-century, they began to break their silence and attempt to speak to the readers in a genuine voice. They share the drive to reassess and redefine themselves in the Past, Present and Future. This article deals with the way in which the four Women Poets, Ntozake Shange, June Jordan, Lucille Clifton and Audre Lorde deal with the issues of gender; they unanimously express their anger and indignation on Black female subjectivity and also convey their pleasure, while celebrating their womanhood.
\end{abstract}

Index Terms - black women, race, gender, dual colonialism, black oppression, double standard, African American female subjectivity, duality of black womanhood, sexual exploitation of black girls

The literary works of Black American women, whether fictional, biographical, autobiographical or poetic seem to share a theme that speaks to Black women's spirit. Lisa Jones says a Black woman is like bullet proof diva, "whose sense of dignity and self cannot be denied; who though she may live in a war zone, goes out everyday greased, pressed and dressed... she has the lip and nerve and she uses that lip and nerve to raise herself and the world" (Lisa Jones 3)

Black women poets of late twentieth century United States have been driven into a quest for identity. They address the two questions: How do we assert our identities in a world that prefers to believe we do not exist? How can we control our rage as well as express our love and warmth for fellow beings?

The literary history of Black American women poets in the eighteenth and nineteenth century had a beginning in the work of Lucy Terry, Phillis Wheatley and Harper and their sister poets. Yet, their history was neither documented nor appreciated. The women's participation in the Harlem Renaissance was not hailed at the beginning. Black feminist critics while analysing the nineteenth-century African American women literature say how African American women were genderless during the period of slavery and how they were alienated from the aspects of mainstream feminity:

Since (black) women, no less than men, were viewed as profitable labor-units, they might as well have been genderless as far as the slaveholders were concerned. In the words of one scholar, "the (black) woman was first a full time worker for (the landowner) and only incidentally a wife, mother and homemaker". Judged by the evolving nineteenth century ideology of feminity, which emphasises women's roles as nurturing mothers and gentle companions and house keepers for their husbands, black women were practically anomalies. (Davies 5).

So, even during the period of slavery, the White landlords were under the perception that Black men and women had an equal capacity for hard labour. In the White dominant society, she was genderless. During the reconstruction era, Black women also had played a heroic role in the struggle for freedom and equality. Harriet Tubman, Sajourner Truth, Rosa Parks, Daisy bates, Ella Barker, Famie Lou Homer, Coretta Scott King, Ruby Dorris Robbinson, Angela Davis to name a few. When one studies African American literature in the beginning, one can find that there was one of conspicuous omission, the study of Black women poets and the neglect is historical. In Black Feminist Thought, Patricia Hill Collins writes:

The shadow obscuring the black women's intellectual tradition is neither accidental nor benign; Suppressing the knowledge produced by any group, makes it easier for dominant groups to rule because the seeming absence of an independent consciousness in the oppressed can be taken to mean that subordinate groups willingly collaborate in their own victimization, maintaining the invisibility of black women and our ideas in critical, in structuring patterned relations of Race, gender and class inequality that pervade the entire social structure. (Collins 63)

Some Black women poets' works exist only in anthologies. Many were not so fortunately preserved. In the "Incidents in the Life of a Slave Girl", Linda Brent writes that slavery is terrible for men but it is more terrible for women because, added to the burden common to all, they have wrongs and sufferings and mortification peculiarly of their own. These Black women writers were the victims not only of a social injustice but of a sexual arrogance synonymous to dual colonialism. They have had to fight against two battles one against White oppression and another against the Black oppression. Hence male writers, who portrayed the women, did it only at the surface level. Black women shared equally in the labour and strife for Black people, but they invariably seemed to live for others; for Black 
men and White; for children; for parents and not for her independent self. When history shaped into tradition, women were deleted from the texts. Black men were shown as the slave, fiery orator, the political activist, but the heroic voice of the Black woman got suppressed and they were disinherited. They faced the racial and sexist oppression crippled by poverty. Black women did not have control of the institution that could print their work. But, there was no lack of intellect, imagination and energy among Black women. They continued to write in their poetic tradition.

Probably, the first African American woman poet was Lucy Terry (1730-1821) who wrote about an Indian ride on Deerfield Massachusetts. More familiar is Phillis Wheatley (1735-1784) the eighteenth-century slave who was one of the best known poets of her time. She wrote:

I, young in life, by seeming cruel fate

Was snatch'd from Africa's fancy'd happy seat:

What pangs excruciating must molest

What sorrows labour in my parent's breast?

Steel'd was that soul and by no misery mov'd

That from a father seiz'd his babe belov'd:

Such, such my case. And can I then but pray

Others may never feel tyrannic sway? (Julian 50-51)

These lines written in 1772, prior to this country's own war for freedom, were expressed by Wheatley. This love for freedom and a search for place in an alien culture are themes that have persisted through two centuries of African American women's poetry.

Sajourner Truth's (1797-1883) Ain't I A Woman? a speech at the Akron, Ohio women's Rights convention in 1852 has been adapted into the poetic form by Erlene Stetson, and its title remains a cry for oppressed women everywhere:

Ain't I a woman?

Look at me

Look at my arm!

I have plowed and planted

and gathered into barns

and no man could head me...

And Ain't I a woman

A woman can't have as much rights as a man

cause Christ wasn't a woman

Where did your Christ come from?

From God and a woman!” (Stetson 25)

Mid-nineteenth century novelist Frances E.W. Harper (1825-1911) published nine volumes of poetry and spoke strongly for the freedom of African Americans. She was the foremost woman poet to sound out the men in her poems. In "Double Standard", she expresses:

Crime has no sex and yet today

I wear the brand of shame;

Whilst he amid the gay and proud

Still bears an honored name

Can you blame me if I've learned to think

Your hate of vice a sham,

When you so coldly crushed me down

And then excused the man? (Stetson 26)

Harper's protest poetry focused on the right of women to rebel against the unjust laws of American society. She was followed by Georgia Douglas Johnson (1886-1966) whose, The Heart of a Woman and other poems appeared in 1918. Between Harper and Johnson, poems of other female African Americans such as Angelina Weld Grimke (1880-1958), and Ann Spenser (1882-1975) were published in anthologies, but they produced no individual volumes of poetry.

Grimke was one of the earliest lesbian poets and Spenser was a Seminole Indian. Jesse Fauset (1888-1961) a much anthologized poet, was widely read during the Harlem Renaissance of the 1920s. Women's literature during renaissance dealt with identification with the race, expressing a militant proud spirit, anger at racism, determination to fight oppression and rejection of White American culture. Anne Spencer addressed lynching, female subordination and racism. In her poem "White Things", she writes:

They pyred a race of black, black men

And burned them to ashes white; then,

Laughing, a young one claimed a skull,

For the skull of a black is white, not dull,

But a glistening awful thing 
Made, it seems, for this ghoul to swing

In the face of God with all his might,

And swear by the hell that sired him:

"Man-maker, make white!" (Shadowed Dreams 49)

Georgia Douglas Johnson reflected on prejudice and cultural imperialism, the strength of their ancestors, Black culture and the beauty of their colour and their hope for freedom.

In the poem "Armageddon", she says:

In the silence and the dark

I fought with dragons:

I was battered, beaten, sore,

But rose again

On my knees I fought, still rising,

Dull with pain!

In the dark I fought with dragons-

Foolish tears! cease your flowing!

Can't you see the dawn appears? (Shadowed Dreams 62)

In some of the verses they explored the forbidden topics of sexual attraction and freely wrote their erotic attraction for women.

The literary history of Black women poets in the eighteenth and nineteenth- century began with the work of Lucy Terry, Wheatley, Harper, Douglas Johnson and their contemporary women poets. Before 1890s, there was no book of poetry published other than the books of Wheatley and Harper. In the beginning, women's writing was considered singular and abnormal, not universal and representative. More than that, writing about Black women was not considered as racially significant as writing about Black men. Thus, when the Black writers sang against the racial oppression, all of the Renaissance women of the 1920s continued the tradition of voicing their opinion about the oppression within the race. Alice Nelson Dunbar writes:

Black emphasis must be not against White but for Black. In the conference that counts...there will be neither looking up nor looking down. It frightens me to realize that I had died before the age of fifty; I would have died a Negro fraction. (Marie Evans 75)

Treating the subjects ranging from the revolution to institutionalised religion, these poets have brought a sensitivity and insight to their work that is distinctly Black and female. As a result, the role and the treatment of Black women have been focused. It in turn, resulted in Free Speech Movement, The Peace Movement, The Gay Movement and The Woman's Movement. When Black women discovered a political context that involved both race and gender, it took a special turn and women's literature. African American writers differed from their male counter parts in the manner in which they treated the subjectivity of their major protagonist; to define their selfhood and to define their being in their own terms and their special need to speak about feminine concerns. The women writers knew that it was necessary to tell their story. It often meant telling a story of imprisonment without liberation, of struggle without resolution, of pain without relief. They echoed the writers of a hundred or even two hundred years ago to deal with, a contemporary issue. As a result, the Black literature had been enriched and expanded. Black female writers often claimed descent from other Black women literary ancestors such as Zora Neale Hurston and Ann Petry. The writers of Black Literary Movement had been intent upon bonding with other women. Several important anthologies such as Mary Helen Washington's

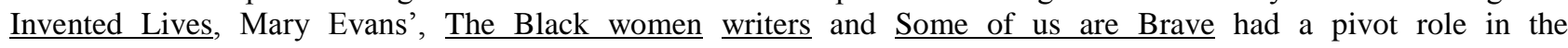
institutionalisation of Black women in literature.

Then came Margaret Danner, Margaret Walker, Gwendolyn Brooks, Maya Angelou, Alice Walker and more. In the 1960s, a tornado of Black women poets occurred-Sonia Sanchez, Nikki Giovanni, Carolyn Rodgers, Lucille Clifton, Fabio June Jordon, Audre Lorde, Mari Evans, Rita Dove and the like. Many are still growing. Even some of the Black women writers such as Nikki Giovanni, June Jordon, Audre Lorde and Rita Dove introduced political writing. Sonia Sanchez and Jayne Cortez blasted the issues of racism and sexism boldly in their poems. In the literary techniques and forms, African American women poets have made and are making very substantial contribution to the literature. A brand new generation of women poets is on the scene, all of whom are within and extending tradition.

Owing to the historically extraordinary oppression of women of African descent in the world, the literary tradition of African American tradition is a separate and unique tradition. The tradition constitutes the legacy handed down from generation to generation of Black women poets. Their poetry deals with the elements of women's lives and women's aspirations in women's terms; child bearing, girlhood, aloneness, love and un love, deaths, survivals, dreams, struggles and transformations.

Barbara Christian analyses the development of woman writers' tradition between 1892 and 1976:

a rich and powerful tradition of black women writers...involving the variety and richness of the black women's experience... challenging the very definition of women and project their very definitions themselves' transferring the contents of their communities' views on the nature of woman therefore on the nature of life renewing the tradition while 
sustaining them...these story tellers both oral and literary transform gossip, happenings into imposter of factual events, images, fantasies and fables critical not only of an individual but of the entire social fabric. (Black Women Novelists 153)

In late twentieth century, Black women poets started to address African American female subjectivity and take up the question of dual identity, as well as Eurocentrically based conceptions of the real that have maintained womanhood as a White, middle-class identity category. They also renegotiated these assumptions about identity that understood antiracist action in terms of African American males. They dealt with the issues like rape, female sexuality, and marriage roles like sister, daughter and mother which had been framed by White women. They started to celebrate their weaknesses to conform to mainstream notions of feminity and women's role that had consigned to Black women to silence.

Ntozake Shange, June Jordan, Lucille Clifton, Audre Lorde are some of the prominent poets of late-twentieth century. Their goal is to emphasise the counter hegemonic position of Black female subject. The female body created by these poets celebrates its womanhood and they willingly come out of traditional settings and roles. They have used imageries to create a Black female body to resist the narrow definitions of womanhood.

Shange was the first of these poets to gain popularity among the readers. She is best known for her work, "For coloured girls who have considered suicide when the Rainbow is Enuf” (1976). The poems of Shange's, "Nappy Edges" (1978) open with a short poem that defends the title, 'Nappy Edges.' The expression refers to the straightened hair of African American women which is turning back to its original state because of exposure to water and humidity. She defines:

The roots of your hair/ what

turns back when we sweat, run,

make love, dance, get afraid, get

happy; the tell tale sign of living/ (Nappy Edges 3)

Shange locates the readers to be Black and female. It is not an invitation to those in the century who exist outside this dual identity. In choosing the title as an idiom intimately associated with African American Women's bodies, activities and standards of beauty, Shange locates the voices of the Black audience. Another poem, "resurrection of their daughter", traces a young African American woman's journey to self-invention and discovery who freed herself from the social constraints of Black Bourgeoisie. The daughter's family strictly adheres the social conventions. It is proud of its daughters who:

... cd set a formal table

curtesy as if not descendants of slaves

$\&$ speak English with no accent at all

they were virgins for a long time (resurrection 90)

The daughter of this poem is a fugitive form the chaste sensibilities of an African American middle class which leaves no space for the sexual expression of single Black woman. The portrait of this daughter highlights Black women's willful departure from traditional paths to empowerment.

Shanges', "Oh, I'm 10 Months Pregnant" is a whimsical allegory in which the poet uses the unlikely image of the Black women poet in her tenth month of pregnancy. African American figure is embodied in the unborn girl child developing within the Black female body of the mother. The mother capitulates to the wishes of her daughter to emerge not as a simple physical being, but as a discursive figure:

i finally figured out what to say

to this literary die-hard of a child of mine

"you are an imperative my dear" \& i felt her startle

toward my left ovary than I said "as an imperative

it is incumbent upon you to present yrself" (A Daughter's Geography 31)

Thus, Shange's Black mother woman wants her unborn daughter to be a revisionist image. June Jordan attacks the White man's belief in his racial and sexual superiority by challenging the public images of the father of the American Republic, George Washington. The poet underlines the gap between the two leaders' high religious and political ideals expressed in public and their dehumanizing treatment of women slaves in private. In "Cameo No. II", she calls Washington, "George, the father hypocrite" and presents him as an:

aristocratic raider at the vulnerable

slavegirl bed

Americanus Rex

Secretus Blanco-Bronco-Night-Time-Sex

the father of this country

leading privileges of rape and run (Things that I Do in the Dark 116)

June Jordan similarly plays the role of witness in "Unrecorded Agonies", in which she refers to the death of a 19 year-old Black woman who was gang-raped on a Brooklyn roof and then thrown off in to the river. Though she 
screamed, it was inaudible. Her murder was unrecorded and unremembered and she joined the group of already murdered Black women whose raped bodies were never answered by the White Law.

In "The Rationale" from the book Passion, Jordan presents with irony the mentality prevailing in male-dominated societies that rape is a crime of passion usually caused by the victim. In this view, any woman who walks alone, especially at night, is prone to trouble, because her mere presence is a provocation for passing men. If she looks foreign, sexy and fast, as the woman does, then the provocation increases. When, therefore, a man loses his control and rapes her, it is her fault but his aggressive behaviour is considered normal. Yet, Black females are not exposed to danger only when they are in public places.

Sometimes, young girls often face even greater danger of sexual assault in their own homes. The rapist describes how he raped her and also how he broke the car and got into it. Yet, the difference lies in the value that a capitalist patriarchal society attaches to the car and the woman. The man is arrested again for the theft of somebody's expensive car and will certainly be sentenced for violating property laws. There is no indication in the poem, however, that he will be sentenced for the rape. This is because the woman, who is also considered an object and is treated as such, has no male owner. It is not accidental that Jordan does not give the woman the chance to speak about her rape and the rapist. The woman's silence suggests her subordinate position, which does not allow her to define herself and her experience in her own terms:

I looked all around to see where her

owner/where the man in her life could

probably be. But no show. She was out.

By herself. On the street:

As fine, as ready to go as anythin you could

ever possibly want to see so

I checked out myself: what's this?

Then I lost my control; I couldn't resist.

What did she expect? She looked foreign

besides and small and sexy

and fast

by the curb. So I lost my control and

I forced her open and I entered

her body and I poured myself

into her

pumpin for all I was worth

wild as I was

when you caught me

third time apprehended

for the theft of a Porsche. (Passion 11-12)

In "Poem about my Rights", Jordan speaks more directly about the political nature of rape, and reveals the interconnection of racist, sexist and economic factors. At first, the speaker protests against the multiple obstacles, rejections and dangers she has faced because of her difference from those in power. She then parallels the sexual and other abuses she has suffered as a Black woman in the USA, with the rape of African countries by the forces of neocolonialism. She concludes that she has paid a high price for her difference, but, instead of feeling defeated, she asserts her determination to retain her identity and to fight back against her oppressors:

I have been raped

be-

cause I have been wrong the wrong sex the wrong age

the wrong skin the wrong nose the wrong hair the

wrong need the wrong dream the wrong geographic

the wrong sartorial I (Passion 89)

The lack of social protection and the need for women of colour to develop their own skills in self-defence are also pointed.

Like Shange, Clifton knows what is to be a Black woman in America. Even when she speaks of her enemy she is not harsh. She is humane while referring to their enemy:

he heads, always for a cave

his mind shivers against the rocks

afraid of the dark

afraid to be alone

afraid of the legendary creature

who is Black

and walks on grass 
and has no need for fire (Good Times 15)

Race contributes to the meaning of Clifton's other poems about womanhood. In the poem "the lost baby" (Good news about Earth), the poem is addressed to the baby lost through abortion. The poem is elegiac in tone and it is similar to Brooks' poem "mother". The mothering "the lost baby" explains the reason why she not to have the aborted baby. At the time of pregnancy, her family was very poor. Even if she had delivered the baby, she would have given the baby for adoption:

you would have been born in winter

in the year of the disconnected gas

and no car

we would have made the thin walk

over the genecy hill into the canada winds

to let you slip into a stranger's hands

if you were here i could tell you

these and some other things (Good news about Earth 60)

Even if the child had born, it would have had a bad start in its life:

You would have been born in winter

in the year of the disconnected gas

and no car

The mother says that the child would have fallen into the snow and died. The mother threatens herself with the punishment mentioned in the Old Testament for the sinners. Anyhow the mother feels a special obligation to her own Race. She has destroyed a being in the Black Race and it is a sin to be punished.

In the poem "Monticello" (Good woman), Clifton ridicules the hypocrisy of the politicians who say that they are against the system of slavery. She makes an ironic reference to the gap between Jefferson's statement s and his private actions. Although Jefferson stressed in America's declaration of independence from British colonial rule that all men are created equal. He himself was a big plantation owner and slave holder. Like other slaveholders, he used Black women slaves as field workers and sleeve breeders and objects of sexual pleasure. So, she ironically says:

God declares no independence.

here come sons

from this Black sally

branded with Jefferson hair (Good woman 126)

In the poem "What the mirror said", Lucille Clifton creates a strong and assertive woman who embraces her sexual and personal identity happily. Even the title indicates Clifton's confidence in seeing her own identity reflected in the mirror. In the poem, the narrator is the image in the mirror, telling the woman standing in front of it:

listen,

you a wonder.

you a city

of a woman.

you got a geography

of your own.

listen,

somebody need a map

to understand you (The woman that I am 57-58)

The image reflected back to the woman standing in front of the mirror is bigger than life and shows the woman to be a wonder and a city of a woman with geography of her own, one which somebody will need a map in order to negotiate. This imagery suggests that instead of taking directions, the image in the mirror reassures the woman before it that somebody needs directions to move around her that she is not a girl without name and place as Black women were during slavery, but she is some body with the identity. Clifton emphasizes, with pride and confidence, the identity of her woman character, women of all Races can identify with the poet on issues related to Gender prescriptions that tend to cut across all cultures, such as the need to be beautiful and the feeling that one is not meeting cultural standards.

Clifton's poems often challenge the pervasive attitudes of the society. Women especially Black women become the victims of the adversary or the non-entity. The poem "There is a girl inside" focuses on an old woman's vitality:

She is a green tree in a forest of kindling

he is a greeen girl in a used poet (Good Woman 170)

The body of the old woman may look old but like a nun, she is waiting for the second coming:

when she can break through gray hairs

into blossom

Effectively combining the images of nature and sex, the poet concludes:

and her lovers will harvest

honey and thyme

and the woods will be wild 
with the damn wonder of it

For this old woman one lover is not enough. More than one lover is expected. If given an opportunity she will inspire and gratify those around her. Clifton proposes through this poem that it is no matter what is the age of a woman. She is a wondrous resource, waiting to be tapped creatively and sexually. The girl inside every woman is not only sexy but also amazingly strong. Clifton's vision is a uniquely a female vision.

Lorde also deals with the duality of Black womanhood. In, "A Woman Speaks", Lorde uses the theme of magic and timeless nature to explain the Black woman's subjects' capacity to transform:

Moon Marked and touched by sun

my magic is unwritten

but when the sea turns back

it will leave my shape behind (1-4)

Black womanhood endures as the planets and seas endure. Blackness and womanhood combine in the African American female body. Her 'endurance' here means her ability to transform into transcend the boundaries of past, present and future.

The poem "Need: a Choral of Black Women's Voices" deals with the issues of race as well as gender. Lorde assumes the role of the witness to the Black man's sexual crimes and the spokesperson for his victims 'whose blood is shed in silence' because of society's indifference. The shedding of blood denotes the waste of Black lives and the failure of love in a social environment divided by racism and sexism:

I: Dead Black women haunt the black maled streets

paying the cities' secret and familiar tithe of blood

burn blood beat blood cut blood

seven year old child rape victim blood blood

of a sodomized grandmother blood blood

on the hands of my brother blood

and his blood clotting in the teeth of strangers

as women we were meant to bleed

but not this useless blood (Complete Poems of Audre Lorde 350)

With great poignation, she presents the unrecorded and unremembered murder of a young girl who was raped and murdered in a public place.

In another poem "Chain", Lorde illustrates how a young girl is facing even greater danger of sexual assault in her own home. From the newspaper report of the case of two girls sent to foster homes as they had borne children by their natural father, Audre Lorde recreates the story in her own poems. In an imaginary dialogue with the mother figure, Lorde makes the girl explain how their father coerced them into having sexual intercourse with him:

but he said if we did it then

we would be his

good children if we did it

then he would love us (Complete Poems of Audre Lorde 247)

Lorde also points out the girls' consequent confusion about their identities and their relationships with each of their parents and with children, they bore their father:

Am I his daughter or girlfriend

am I your child or your rival

you wish to be gone from his bed?

Here is your granddaughter mother

give us your blessing before I sleep

(Complete Poems of Audre Lorde 247)

In addition to the sexual exploitation of Black girls and teenagers, the sexual harassment and rape of adult Black women in contemporary society is a frequent theme in her poems.

In the poem "Hard Love Rock \# 2", Lorde questions the male nationalists who devalue and subordinate the sexual exploitation of their racial sisters. She doubts the Black male's ability to improve the condition of their race by slogans or by rhetorical questions. She sarcastically refers to the men's frequent distortion of the popular slogan 'Black is beautiful' as an excuse to satisfy their lust. Her female speaker expresses her anger against this distortion and the sexism it hides:

Black is

not beautiful baby

beautiful baby beautiful

lets do it again

It is

not

being screwed twice

at the same time 


\section{from on top}

as well as

from my side. (Complete Poems of Audre Lorde 125)

The poet vehemently attacks the hypocrisy and the lust of the Black nationalists, who have promised the Blacks for freedom. She also points out the lack of cohesion and order in the Black community.

In "Scar", Lorde explains the intense constructive power of recognition of African American with one another. When one Black woman recognizes another, it brings a lot of happiness. In that crucial moment, they indirectly acknowledge that they share a common place origin. The emphasis in this poem is upon the ways which women subjects invent each other. Lorde provides this scene of women dancing together by moon light as an allegory for the transmission of the traits of Black womanhood not from mother to daughter, but among women of the same generation. She says:

Only a tideless ocean of moonlit women

in all shades of loving

learning the dance of open and closing

learning a dance of electrical tenderness

no father no mother would teach them

Lorde traces the Amazon's origin in African community in which women were considered as a symbol of power and strength. In Amazon warriors who cut their breasts wilfully, Lorde finds the source of Black female power. By providing those African models, she sees the Black woman's struggle as a continuation of long struggle.

In the last quarter of the twentieth century, African American women poets reclaimed the Black women's body by recreating the meaning of its component parts, Blackness and womanhood. They have proved themselves as artists, as capable of intellect and creative talents. Through their poetry, one can understand that though they are different in their treatment of theme and stylistic devices, they all have a common vision of a society free of race and gender discrimination. All these poets use poetry as a means of expressing their anger over the prevailing realities. They can grapple with contemporary issues as well as the questions of existence and meaning of survival. Consciously as well as unconsciously, these Black women poets express the hurt in their body and soul. They use gendered and racial imagery, as well as the Black American idiom, ellipses, fragmented words or lines, and the violation of punctuation, grammar and syntax so effectively to express Black woman's experiences and struggle for meaningful existence. They also reveal the ideological, socio-political, and economic factors for the devaluation of the Black woman as a human being. They also have trapped her as the victim of male sexual and racial politics. They also want to change the prevailing stereotype of the Black woman who is scared of the sexual abuse. They show the brutalising effects of such continuous abuse on her body and consciousness.

Through their severe criticism, they reclaim the Black American woman's control of her colonised body, life, and speech. They advocate the urgent need for the creation of a truly egalitarian and more humane society with greater respect for all its members. These poets understand time and again as Lorde implies, "Poetry is not a luxury", the act of not writing at all would be asphyxiating and would ultimately equal to the death of the poet. The above discussed poems read the African American female Body through the lens of the experiences of the poet which is rooted in each poet's perspective as a Black woman.

\section{REFERENCE}

[1] Clifton, Lucile. (1970). Good Times. New York: Random House.

[2] Clifton, Lucile. (1976). An Ordinary Woman. New York: Random House.

[3] Clifton, Lucile. (1970).Good News About the Earth. New York: Random House.

[4] Clifton, Lucile. (1987).Good Woman: Poems and a Memoir 1969-1980. Brockport, New York: BOA.

[5] Davies, Angelou Y. (1983). Women, Race and Class. New York: Random House.

[6] Evans, Mari. (Ed) (1985). Black Women Writers (1950-1980): A Critical Evaluation. New York: Doubleday.

[7] Hill, Collins. (1991). Black Feminist Thought. New York: Routeledge; Chapman and Hall Inc.

[8] Honey, Maureen(Ed) (1989). Shadowed Dreams: Women's Poetry of the Harlem Renaissance, New York: Rudgers University Press.

[9] Jones, Lisa. (1994). Bullet Proof Diva: Tales of Race, Sex and Hair. New York: Bantam Doubleday Dell Publishing Group.

[10] Jordan, June. (1997) Kissing God Goodbye. New York: Anchor.

[11] Jordan, June. (1990). Naming our Destiny: New and Selected Poems, 1989. New York: Thunder's Mouth.

[12] Jordan, June. (1980). Passion: New Poems, 1977. Boston: Beacon Press.

[13] Jordan, June. (1977). Things That I Do in the Dark. New York: Random House.

[14] Julian D. Mason, Jr. (Ed) (1989). The Poems of Phillis Wheatley. Chapel Hill NC: University of North Carolina Press.

[15] Lorde, Audre. (1997). The Collected Poems of Audre Lorde. W.W. Norton, New York.

[16] Shange, Ntozake. (1976). For Coloured Girls Who have considered Suicide When the Rainbow is Enuf. New York: Macmillan.

[17] Shange, Ntozake. (1978). "nappy edges", Nappy Edges. New York: St. Martin's.

[18] Shange, Ntozake. (1978). "resurrection of the daughter", Nappy Edges. New York: St. Martin’s.

[19] Shange, Ntozake. (1983). “Oh, I'm 10 Months Pregnant”. A Daughter's Geography. New York: St. Martin's.

[20] Stetson, Erlene. (Ed.) (1981). Black Sister: Poetry by Black American Women, 1746-1980. Bloomington: Indian University Press. 


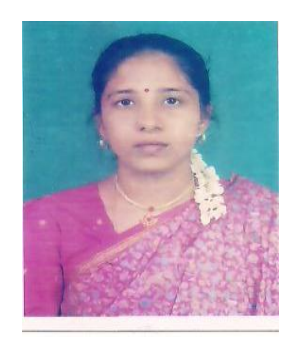

Vijaya K Raman is a lecturer in the Department of English, Rajalakshmi Engineering College, Chennai, India. She was born in Sivakasi, South India. She is an M.A., M.Phil., in English Literature. She had her education in South India. She was awarded the seventh university rank during her under graduation from Madurai Kamaraj University. She got her post graduation degree from the prestigious Lady Doak College, Madurai. She completed her M.Phil., degree in Madurai Kamaraj University. She has submitted her Ph.D. dissertation on African American Women Poetry in The University of Madras and eagerly waiting for vivavoce.

Her keen interest is teaching English to technical students. Her articles have appeared in many web journals. She is a regular contributor to the web journal, Language in India. Some of her publication topics include 'The problem of teaching and learning tenses', 'A Critical Study of the Wasteland: Poetry as metaphor' and 'A Micro-Case Study of Vocabulary Acquisition among First Year Engineering Students'. Her aim is to facilitate communication skills effectively among engineering students. 